\title{
Description of Students' Mathematical Creative Thinking Skills Reviewed From Gender Differences
}

\author{
Malim Muhammad ${ }^{1}$, Elma Hidayatun Nikmah ${ }^{2}$ \\ \{malim.muhammad@gmail.com ${ }^{1}$, elmahidayatun03@gmail.com ${ }^{2}$ \} \\ Department of Mathematics Education, Faculty of Teacher Training \\ and Education, Universitas Muhammadiyah Purwokerto
}

\begin{abstract}
The study describes students' mathematical creative thinking skills in terms of gender differences in quadrilateral and triangular materials. The type of research used is qualitative descriptive research. The subjects in this study were students of class VII C of State Junior High School 2 Gumelar using purposive sampling techniques. Researchers took three male students and three female students as research subjects. The data analysis techniques used in this study include data reduction, data presentation, and conclusions. From the data presented, the data validity test was conducted using triangulation techniques. Data obtained of test results of students' mathematical creative thinking skills, interviews, and documentation was used to describe students' mathematical creative thinking skills using the triangulation technique. There are four indicators used in research, namely smoothness, authenticity, detail, and flexibility. The results showed that male students could master one indicator of mathematical creative thinking ability: authenticity. While female students can master indicators of mathematical creative thinking skills, namely smoothness, authenticity, and detail, but cannot master the indicators of flexibility.
\end{abstract}

Keywords: Mathematical creative thinking skills, Gender, State Junior High School 2 Gumelar

\section{Introduction}

During the Covid-19 pandemic, the learning process in Indonesia experienced a paradigm shift in the way students learn. This causes learning to be done online either with the guidance of parents or without direction. Therefore, most students have not been able to adapt themselves to face the challenges and activities that they must complete in the learning system that is done online or online. Not all students will be successful in online learning and get maximum results. Nakayama [1]. In education, the ability to think mathematically until now still received less attention from both students and teachers. Zheng Zhu found that one factor can cause the ability to think students mathematically in each individual is different. That factor is the gender factor.

Gender is cited as one of the factors that can affect it because it is suspected that there is a difference in ability between men and women [2]. Gender is the difference between a man and a woman based on society's social and cultural constructs, not from the biological condition of a human being [3]. Gender differences cause some people to have thoughts about whether the way a person thinks and learns is also different. Likewise, with students' mathematical creative thinking skills, most people must think whether students' mathematical creative thinking skills are also different because they are influenced by gender differences [4]. But the gender 
differences also cannot fully conclude more clearly which men and women are superior to their creative mathematical thinking skills [5]. The expected goal in the research conducted by researchers is to describe the mathematical creative thinking skills of 2 Gumelar State Junior High School students in terms of gender differences in covid-19 conditions.

Mathematical thinking, commonly called the ability to think at a high level in mathematics, consists of several abilities: thinking systematically, logically, critically, creatively, analysis, systematic problem solving, reasoning, and communication [6]. High-level mathematical thinking skills need to be continuously improved and developed. One of them is the ability to think creatively. According to Suryadi and Herman (Putra, 2016), creative thinking skills are a form of thinking to express new relationships, form new combinations, and see things from a new and different perspective [6]. Munandar [7] also defines that creative thinking skills are a thinking ability that is used to obtain many alternative answers to problems or problems with the emphasis of the answer focused on accuracy, diversity, and the many alternative solutions provided. In this study, researchers used the following indicators of mathematical creative thinking skills:

1) Fluency includes a student's ability to solve problems and provide more than one answer to a particular math problem.

Flexibility includes the student's ability to provide answers with many polishing strategies to certain mathematical problems.

2) Originality includes students' ability to use new, unique, unusual strategies, and rarely given by most students in solving certain mathematical problems.

3) Elaboration includes the student's ability to solve certain mathematical problems by expanding an idea and detailing the details of an answer.

Based on the results of observations made with the Teacher of Mathematics at SMP Negeri 2 Gumelar, in the situation and conditions in the Covid-19 pandemic today, students of State Junior High School 2 Gumelar can think mathematically diverse creatively. This is evidenced by the student learning results in the form of daily assignments and replays given by the teacher of subjects where students' answers when working on the given problems are very diverse [8]. Some students can give varied answers, and some have not been able to develop answers that are given or can be said to be monotonous.

\section{Research Methods}

Qualitative descriptive research is a study that describes data in the form of words to produce a clear and detailed picture of Sugiyono [9]. In this study, researchers analyzed the study's results only to describe the students' mathematical creative thinking skills reviewed from gender differences according to established indicators by analyzing the data and presenting facts systematically. This research was carried out at SMP Negeri 2 Gumelar is a Junior High School (SMP) located on Paningkaban Highway, Paningkaban Village, Gumelar Subdistrict, Banyumas Regency. SMP Negeri 2 Gumelar consists of 18 classes. The number of students of State Junior High School 2 Gumelar is 566 students consisting of 180 students in 7 th grade, which is divided into six classes, 197 8th grade students divided into six classes, and 189 9th grade students divided into six classes. In this study, researchers took class 7 , class $7 \mathrm{C}$ as a research subject. Class 7 consists of 24 students consisting of 11 male students and 13 female students. Researchers conducted the study in grade 7C because a maths subject teacher had suggested it. For the selection of samples in this study, researchers chose to use the Purposive 
Sampling technique, which is sampling based on specific goals or considerations. In this study, one class will be selected for a sampling of respondents. In this study, researchers involved the help of teachers to consider samples; the considerations were also seen based on test results on students' mathematical creative thinking skills and selecting students who were easy to interview.

In this study, researchers used data collection techniques in the form of tests, interviews, and documentation. Here is the description of data collection techniques [10]:

1) Written test, in this study, uses written tests to measure the ability of mathematical creative pics of students in the form of 4 (four) questions of description. This written test is done once students receive quadrilateral and triangular materials to analyze students' mathematical creative thinking skills reviewed from gender differences. The preparation of instruments of students' mathematical creative thinking skills begins by determining the purpose of the test, adjusting the test grid, and creating test questions based on material indicators whose characteristics correspond to the grids that have been created. This mathematical creative thinking ability test is shared with students online through the social media platform WhatsApp by sending a soft file test of mathematical creative thinking skills in the research class. Then students also send back the results of the answers to the mathematical creative thinking skills test through WhatsApp to researchers in the allotted time.

2) Interviews conducted in this study are in the form of structured interviews, where the researcher outlines the subject matter. Still, in the implementation later, the researcher does not ask questions sequentially and in the implementation of the interview uses nonstandard sentences so that respondents are relaxed and free in answering questions from researchers. Interviews in the study were conducted to get information on data - qualitative data that researchers could not get from written test results through WhatsApp. In addition, interviews are also conducted to support data that has been obtained based on the results of mathematical creative thinking ability tests from interview guidelines that have been compiled based on indicators of mathematical creative thinking ability. Researchers conduct interview activities to students who have been selected as samples through WhatsApp social media so that interviews can be done through chat or voice messaging features that WhatsApp social media have provided.

3) Documentation is used so that the data obtained from test results and interviews can be trusted because documentation complements the test method and interviews that have been done before-documentation in this study in the form of photos of test results of students.

\section{Results and Discussion}

Data that has been obtained to explain mathematical creative thinking skills reviewed from the gender differences of students is checked using triangulation techniques to be more trusted. As for the complete triangulation table. From the triangulation table inferred for each indicator and gender is obtained:

Table 1. Triangulation of Mathematical Creative Thinking Skills

\begin{tabular}{|c|l|l|l|l|}
\hline Subject & Fluency Indicators & $\begin{array}{c}\text { Flexibility } \\
\text { Indicators }\end{array}$ & $\begin{array}{c}\text { Originality } \\
\text { Indicators }\end{array}$ & $\begin{array}{c}\text { Elaboration } \\
\text { Indicators }\end{array}$ \\
\hline Male & Male respondents & Male & Male & The re male \\
\hline
\end{tabular}




\begin{tabular}{|l|l|l|l|l|}
\hline & $\begin{array}{l}\text { were unable to } \\
\text { provide other } \\
\text { possible answers. }\end{array}$ & $\begin{array}{l}\text { respondents } \\
\text { were unable to } \\
\text { provide more } \\
\text { than one } \\
\text { alternative } \\
\text { solution. }\end{array}$ & $\begin{array}{l}\text { respondents } \\
\text { can answer in a } \\
\text { way that he } \\
\text { thinks is new. }\end{array}$ & $\begin{array}{l}\text { response cannot } \\
\text { answer in a } \\
\text { sequenced or } \\
\text { detailed way. }\end{array}$ \\
\hline Female & $\begin{array}{l}\text { Female } \\
\text { respondents can } \\
\text { give other possible } \\
\text { answers. }\end{array}$ & $\begin{array}{l}\text { Female } \\
\text { respondents } \\
\text { were unable to } \\
\text { provide more } \\
\text { than one } \\
\text { alternative } \\
\text { solution. }\end{array}$ & $\begin{array}{l}\text { Female } \\
\text { respondents } \\
\text { can answer in a } \\
\text { way that she } \\
\text { thinks is new. }\end{array}$ & $\begin{array}{l}\text { Female } \\
\text { respondents can } \\
\text { answer in a } \\
\text { sequence or } \\
\text { detailed way. }\end{array}$ \\
\hline
\end{tabular}

Based on the results of written test descriptions and interviews conducted from six selected students, mastery of indicators of mathematical creative thinking skills students are punched from gender differences in solving mathematical problems can be described. These aspects of creative mathematical thinking consist of aspects of fluency, flexibility, originality, and elaboration. The following are the research results on the mathematical creative thinking skills of State Junior High School 2 Gumelar students in terms of gender differences. Here is an explanation of the research results on the mathematical creative thinking skills of state junior high school students 2 Gumelar reviewed from gender differences in covid-19 conditions. Based on the results of research from written tests, male students cannot understand problem number 1 , which contains fluency indicators. Judging from the three answers from male students, the three gave only one possible answer where two students answered with the right answer and one student answered with the wrong answer. This is shown from the ability of students who can only provide one possible answer to determine one side of the flower garden in the form of a right triangle or rectangle with the size of one side and the area already known.

Overall, the three male students were unable to provide another possible answer to problem number 1 . This shows that male students are unable to master the fluency indicator in question number 1 . As for problem number 2, male students are able to understand the problem well so that they can get the right information from problem number 2 . The three male students were already able to meet the indicator of originality. Because the three male students are already able to give answers that they think are new and unique, this was shown by the answers of the three male students who differed from each other to solve problem number 2 related to drawing a combination of flat wakes that include quadrilateral and triangles that have a circumference of $140 \mathrm{~cm}$. Of the three male student answers related to question number 2, overall, it appeared that all three male students were able to give new and unique answers. Still, only two male students answered with the right answer, and one male student answered incorrectly. This shows that male students have been able to master the indicator of originality because they can provide answers that they think are new and unique.

In addition, for the elaboration indicator on question number 3 of the three male students, only one male student met the elaboration indicator. This is indicated by the answer from one male student who can calculate the circumference of the field and the cost of installing rectangular field barriers in a sequence or detailed way. The three male students, only one male student, gave answers in a sequenced or detailed way, while two male students were unable to answer in a sequenced or detailed way. 
Overall, male students are unable to answer in such a sequenced or detailed manner that it can be said that male students cannot master elaboration indicators. As for problem number 4 , which contains flexibility indicators, it is seen that male students are unable to understand problem number 4 . The three male student answers show this, all three of which cannot provide an alternative solution of more than one or only provide one alternative solution. Although the three male students were only able to provide one alternative solution, the three male students were able to correctly determine the area shaded from waking flat on question number 4 . This shows that male students cannot master the flexibility indicator because they are only able to provide one alternative solution to problem number 4 . Based on the research results on written tests, female students can understand problem number 1 , which contains fluency indicators. It is seen that female students can provide other possible answers that are different and also true. The three female students provided two different possible answers to look for the size of the other side of the right triangle-shaped flower garden and the other side of the rectangular flat wake.

Overall, the three female students were able to complete it with different possible answers. The results were also correct, so it could be said that female students could master the fluency indicator. For problem number 2, which contains originality indicators, the three female students can understand the problem well. Of the three female students, all three provided answers that they thought were new and unique. This can be seen from the three answers of female students in resolving the problem of problem number 2, who was asked to draw a combination of flat wakes that include quadrilateral and triangular and determine the size of the circumference so that it becomes $140 \mathrm{~cm}$ where all three female student answers are correct and also according to the new and unique.

Overall that female students have been able to master the indicators of originality. In addition, for the elaboration indicator on question number 3 of the three female students were able to meet the elaboration indicator. This is indicated by the answers of the three female students who have the ability to calculate the perimeter of the field and the cost of installing rectangular field barriers in a sequence or detailed way and also true overall that the three female students were able to answer in a sequenced or detailed way and with the correct answer so that it can be said that female students are able to master elaboration indicators. As for problem number 4, which contains flexibility indicators, it is seen that female students are not able to understand problem number 4 . This is shown by the three answers of female students, and all three are not able to provide an alternative solution of more than one or are only able to provide one alternative solution only. Although the three female students were only able to provide one alternative solution, the three female students have been able to give the correct answer in determining the area shaded from waking flat on question number 4 . This shows that female students are not able to master the flexibility indicator because they are only able to provide one alternative solution to problem number 4.

The results of this study are in line with the results of the study Suciyati et al. (2017) that the mathematical creative thinking ability of female students is higher, or it can be said that female students master more indicators of mathematical creative thinking skills compared to male students. Where male students are only able to master one indicator, namely details, and female students master three indicators, namely smoothness, flexibility, and authenticity. In addition, the results of this study are also in line with the results of Novianti' research et al .2018) that students who have high thinking skills are able to meet two aspects of creative thinking skills, namely aspects of affability and flexibility, students with creative thinking skills are being able to meet one aspect of creativity only, while students with low creative thinking skills are not at all able to meet all aspects of creative thinking ability. From the results of research 
conducted by researchers, it is seen that the mathematical creative thinking ability of male students and also female students in covid-19 conditions is the same as before the condition of covid-19 where male students are able to meet the indicators of mathematical creative thinking skills less than female students who are able to meet the indicators of mathematical creative thinking skills more.

\section{Conclusion}

Based on the results of research on the description of mathematical creative thinking skills of state junior high school students 2 Gumelar reviewed from gender differences in the condition of covid-19 in class 7C can be drawn some conclusions that male students are not able to provide various other different possible answers, able to provide answers in new ways or strategies, unable to solve problems in a sequence or detailed way, And unable to provide an alternative answer to the given problem. In addition, the male students are already convinced by their respective answers. So, it can be concluded that male students are able to master the indicator of originality only. It is seen that the ability to think mathematically for male students in the condition of covid-19 is the same as the condition before covid-19, i.e., fewer male students meet the indicators of mathematical creative thinking skills. Female students are able to provide a variety of other different answer possibilities, provide answers in new ways or strategies, solve problems in a sequenced or detailed way, and are unable to provide alternative answers to other problems given. Female students are also confident in the answers they are working on and can re-explain the ways they have been used to solve problems. So, it can be concluded that female students are able to master indicators of fluency, originality, and elaboration. It is seen that the mathematical creative thinking ability of female students in covid-19 conditions is the same as the conditions before covid-19.

\section{References}

[1] Afifah, M.N., Firdha, N.S., \& Firyal. H.A. (2019). Analysis Higher-Order Thinking Skills Siswa SMP

[2] Arbain, J., Nur, A., \& Sari, I.N. (2015). Pemikiran Gender Menurut Para Ahli. SAWWA, 11(1).

[3] Darwanto. (2019). Kemampuan Berpikir Kreatif Matematis. Jurnal Eksponen, 9(2). 20-26.

[4] Dewi, W.A.F. (2020). Dampak Covid-19 Terhadap Implementasi Pembelajaran Daring di Sekolah Dasar. Jurnal Ilmu Pendidikan, 2(1).

[5] Dilla, S. C., Hidayat, W., \& Rohaeti, E. E. (2018). Faktor Gender dan Resiliensi dalam Pencapaian Kemampuan Berpikir Kreatif Matematis Siswa SMA. Journal of Medives, 2(1), 129-136.

[6] Putra, R. D., Rinanto, Y., Dwiastuti, S., \& Irfa, I. (2016). Peningkatan Kemampuan Berpikir Kreatif Siswa Melalui Model Pembelajaran Inkuiri Terbimbing pada Siswa Kelas XI MIA 1 SMA Negeri Colomadu Karanganyar Tahun Pelajaran 2015/2016. Proceeding Biology Education Cobference, 13(1), 330-334.

[7] Purwaningrum, J. P. (2016). Mengembangkan Kemampuan Berpikir Kreatif Matematis Melalui Discovery Learning Berbasis Scientific Approach. Jurnal Refleksi Edukatika, 6(2).

[8] Febrianti, Y., Yulia, D., \& Siti, F. (2016). Analisis Kemampuan Berpikir Kreatif Peserta Didik Dengan Memanfaatkan Lingkungan Pada Mata Pelajaran Ekonomi di SMA Negeri 6 Palembang. Jurnal Profit, 3(1).

[9] Sugiyono. (2016). Metode Penelitian Kuantitatif, Kualitatif, dan R\&D. Bandung:CV. Alfabeta. 
[10] Hidayanti, R., Alimuddin, Syahri, A. A. (2020). Analisis Kemampuan Berpikir Kritis dalam Memecahkan Masalah Matematika Ditinjau dari Perbedaan Gender pada Siwa Kelas VIII.1 SMP Negeri 2 Labakkang. Suara Intelektual Gaya Matematika, 12(1). 